\title{
The Socio-Economic aspects of Health Condition and Morbidity Pattern of Rural Elderly
}

\author{
Shivakumar S. Madagundi ${ }^{1}$, Dr. (Smt) Jayashree ${ }^{2}$ \\ ${ }^{I}$ Lecturer in Sociology ${ }^{I}$, Chairperson ${ }^{2}$, Department of Sociology, \\ ${ }^{2}$ Karnatak University Dharwad-03 Karnataka State, India.
}

\begin{abstract}
Ageing is a multidimensional process; old age is the closing period of the life of an individual. However as already stated the elderly are not a homogenous group. Experts are of the view that it could be divided into three categories; young-old (60-69); old-old (70-79); and oldest-old (80+ years). Each category has different characteristics and many different health problems. It is believed that the real problems of old age affect a person only after 80 years of age. The present study was conducted in Guledgudd Hobli of Bagalkot District with the focus on socio-economic aspects of health condition and morbidity pattern of the rural elderly.

\section{Objectives of the study:}

- To study the socio-economic status of the rural elderly.

- To understand the health problems faced by the rural elderly persons.

Methodology: A total sample 350 Respondents consisting 133 males and 217 females were selected by using the simple random sampling method.

Results: Age and Sex an important criterion which shows the demographic characteristics of survey respondents. 168 (48\%) elderly of them are in the age group of below 60-69 years, followed by the respondents $112(32 \%)$ elderly of them are in the age group of 70-79 years.
\end{abstract}

Keywords: Ageing, Health Condition, Morbidity Pattern, Prevalent Diseases.

\section{Introduction}

Ageing is a natural and universal phenomenon; it begins from the very birth of an individual and continues till death. An individual after his birth gradually crosses the above mentioned stages of life and finally dies. Each and every stage of human development comes with certain hopes, aspirations and achievement and attaining to the old age man tries to find out the last question of his life ${ }^{(1)}$. Neugarten's ideas raise questions above how age should be conceptualized some of the ways in which age has been conceptualized are as chronological age, biological age, psychological age and social age ${ }^{(2)}$. Ageing is a biological process experienced by mankind in all times. "Health is Wealth", health related to a wide variety of factors, including standards of living, life style of living, environment, heredity, educational standards, occupations, diet and nutrition, health services, physical and mental health. There are various problems faced by the rural elderly. Old age in general is associated with multi-dimensional problems. The problems which are associated with age and the care of elderly are not exclusively the problems of social and economic ramifications, rather they include health and medical problems also the affect the life of a community as well ${ }^{(3)}$. According to The World Health Organization (WHO) defines; Health as a state of physical, mental and social well being and not merely absence of diseases or infirmity" ${ }^{(4)}$. Older people are heterogeneous that is extreme losses of physical, mental and social functions are often seen in old people. Yet many people continue to maintain high level of function ${ }^{(5)}$. However as already stated the elderly are not a homogenous group, experts are of the view that it could be divided into three categories; 'young-old' (60-69); 'old-old' (70-79); and 'oldest-old' (80+ years). Each category has different characteristics and different problems. It is believed that the real problems of old age affect a person only after eighty years of age. Elderly or old age consists of ages nearing or surpassing the average life span of human beings. The boundary of old age cannot be defined exactly because it does not have the same meaning in all societies. Government of India adopted 'National Policy on Older Persons' in January 1999. The policy defines 'senior citizen' or 'Elderly population (aged 60 years or above) account for $7.4 \%$ of total population in 200. Both the share and size of elderly population is increasing over time. From $5.6 \%$ in 1961 it is projected to rise to $12.4 \%$ of population by the year $2026 .{ }^{(6)}$ The UN defines a country as 'ageing' where the proportion of people over 60 reaches 7 per cent. In India, currently 7.8 per cent of the populations are elderly and it is expected that this will reach 12.6 per cent in 2025.

Morbidity has been defined as "any departure, subjective or objective, from a state of physiological well being. The term is used equivalent to such terms as sickness, illness disability WHO expects committee on health statistics noted on its $6^{\text {th }}$ Report that morbidity could be measured in terms of three units. i) person who 
were ill, ii) the illnesses (provides of spells of illness) that these persons experienced and iii) the duration (days, weeks etc.,) of these illnesses. The aged population has special health problems that are basically different from those of adult or young. Most diseases in aged are chronic in nature-cardiovascular, arthritis stroke, cataract, chronic infections and cancer etc., disease process are usually multiple ${ }^{(7)}$.

Morbidity pattern among the elderly varied from country to county. Chronic conditions which produced infirmity and disability became more common in old age. Morbidity is the extent of illness (disease) injury, or disability in a defined population. Particularly in circumstances of low mortality such as exist now in the industrialized nations, morbidity data give a fuller description of the physical well being of a population than do mortality date ${ }^{(8)}$.

\section{Objectives of the Study:}

The main objectives of the study are follows;

1. To study the socio-economic status of the rural elderly.

2. To understand the health problems faced by the rural elderly persons.

3. To examine physiological and psychological problems of the rural elderly.

4. To understand the morbidity status of the rural elderly.

\section{Hypothesis:}

1. The most rural elderly persons have a multiple health problems.

2. Elderly widowers feel more depressed as compared to elderly widows.

\section{Review of Literature:}

The health and well being of the elderly are affected by many aspects of their social and physical environment. These include life-style, marital status, age and sex, morbidity pattern of the rural elderly. Various studies in the past (Blazer D.G. 1982; Zuckerman D.M. et al 1984; Schoenbach et al, 1986; Sugisawa et al 1994; and Norris et al 2003).

K. Vijaya kumar et al (1992) $)^{9}$ conducted a survey in Thiruvananthapuram city, Kerala to assess the health and functional status of the elderly. Out of the 658 elderly covered 20.15 of males and $68.1 \%$ of females were widowed. The women were found to be poorer suffering a lot having more morbidity than the men, in spite of their greater life expectancy. Morbidity due to cancer, CHD, Diabetes, Hypertension and Arteriosclerosis has increased while there was a decline in morbidity among the elderly from conditions like skin diseases, visual and hearing handicaps and multiple orthopaedic problems $(\mathrm{WHO})^{(10)}$.

\section{Materials and Methods}

The research area selected for this study was carried out in the rural elderly persons entire Guledgudd Hobli of Bagalkot District. This study was carried out over a period of six months from June to December 2012. General information about the total elderly population in the study area was collected from According to 2001 Census a Voter list. According to this voter list there were 4558 households having an elderly in habitant of 60 years or above on a sample of 350 elderly aged 60-69, 70-79 and 80+ were selected based on the simple random sampling method. A total sample 350 respondents consisting 217 females and 133 males were Interviewed using questionnaires'. The data was analyzed on the basis of frequencies, percentages and cross tables using the Statistical Programmers for Social Sciences.

\section{Results and Discussion}

Table No.01 Shows Age and Sex an important criterion which shows the demographic characteristics of survey respondents. $168(48 \%)$ elderly of them are in the age group of below 60-69 years, followed by the respondents $112(32 \%)$ elderly of them are in the age group of 70-79 years. The remaining respondents 70 $(20 \%)$ elderly of them elderly in the age category of $80+$ years and above. The majorities were in their altogether 350 elderly people's $133(38 \%)$ males and 217 (62\%) females were contacted at their homes.

Table No. 01 Age and Sex distribution of the respondents

\begin{tabular}{|c|c|c|c|c|}
\hline \multirow{2}{*}{$\begin{array}{l}\text { Sl. } \\
\text { No. }\end{array}$} & \multirow[t]{2}{*}{ Age groups } & \multicolumn{2}{|c|}{ Sex } & \multirow[b]{2}{*}{ Total } \\
\hline & & Male & Female & \\
\hline 01 & $60-69$ & $68(51.1)$ & $100(46.0)$ & $168(48.0)$ \\
\hline 02 & $70-79$ & $37(27.9)$ & 75 (34.6) & $112(32.0)$ \\
\hline 03 & $80+$ & $28(21.0)$ & $42(19.4)$ & $70(20.0)$ \\
\hline & Total & $133(100)$ & $217(100)$ & $350(100)$ \\
\hline
\end{tabular}

Note: Figures in parentheses are in percentage. 


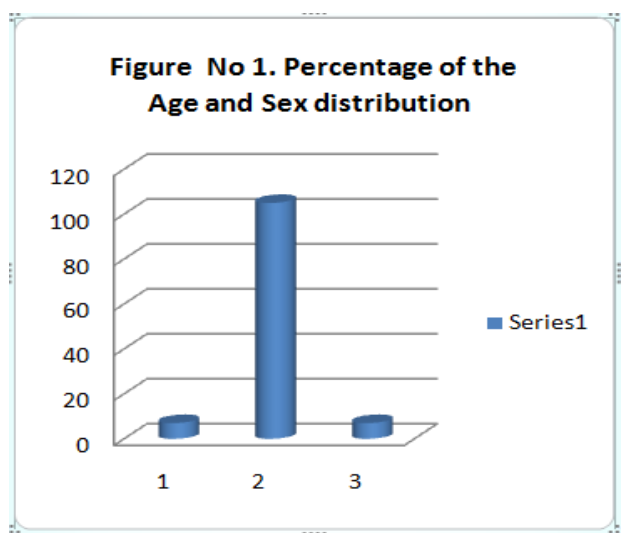

Table No. 02 Type of the Family Structure of the respondents. The Joint Family system is predominant in rural areas and one of the main advantages of joint family system is the availability of a large work fore for occupation. In joint family system there exists a strong differentiation of authority across generations, and a relatively passive role of females. The Majority of the respondents $210(60.0 \%)$ elderly of them belonged to nuclear family and only $140(40.0 \%)$ elderly are joint family system.

Table No. 02 Type of the Family Structure of the respondents

\begin{tabular}{|c|c|r|r|r|}
\hline \multirow{2}{*}{$\begin{array}{c}\text { Sl. } \\
\text { No. }\end{array}$} & \multicolumn{2}{|c|}{ Sex } & \multirow{2}{*}{ Total } \\
\cline { 3 - 5 }$n$ & & Male & Female & $140(40.0)$ \\
\hline 01 & Joint Family & $48(36.0)$ & $92(42.5)$ & $210(60.0)$ \\
\hline 02 & Nuclear Family & $85(64.0)$ & $125(57.5)$ & $\mathbf{2 1 7}(\mathbf{1 0 0})$ \\
\hline & & $\mathbf{1 3 3 ( 1 0 0 )}$ & $\mathbf{3 5 0}(\mathbf{1 0 0})$ \\
\hline
\end{tabular}

Note: Figures in parentheses are in percentage.

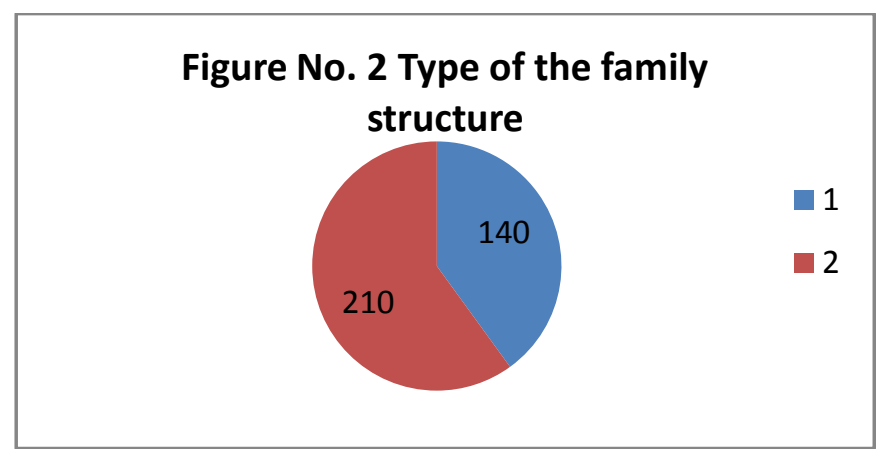

Table No. 03 Shows the marital status of the respondents. The majority were in their $217(62.0 \%)$ of the respondents were female. And remaining $133(38.0 \%)$ of the respondents were male elderly. As for the marital status of the respondents $224(64.0 \%)$ were widowed, and $105(30.0 \%)$ elderly were married $07(2.0 \%)$ are divorced, $07(2.0 \%)$ are remarried, $7(2.0 \%)$ are unmarried. In our study sample we found four male three female elderly who were over 65 years of age and never married. Among the widowed (224) elderly 178 were female and 46 were male our findings show more number of widows in our sample.

Table No. 03 The Marital Status of the respondents

\begin{tabular}{|c|c|c|c|c|}
\hline \multirow{2}{*}{$\begin{array}{l}\text { Sl. } \\
\text { No. }\end{array}$} & \multirow[t]{2}{*}{ Marital Status } & \multicolumn{2}{|c|}{ Sex } & \multirow[b]{2}{*}{ Total } \\
\hline & & Male & Female & \\
\hline 01 & Unmarried & $04(3.0)$ & $03(1.3)$ & $07(2.0)$ \\
\hline 02 & Married & $78(58.7)$ & $27(12.4)$ & $105(30.0)$ \\
\hline 03 & Divorced & $03(2.2)$ & $04(2.0)$ & $07(2.0)$ \\
\hline 04 & Widowed & $46(34.5)$ & $178(82.2)$ & $224(64.0)$ \\
\hline 05 & Remarried & $02(1.6)$ & $05(2.3)$ & $07(2.0)$ \\
\hline & Total & $133(100)$ & $217(100)$ & $350(100)$ \\
\hline
\end{tabular}

Note: Figures in parentheses are in percentage. 


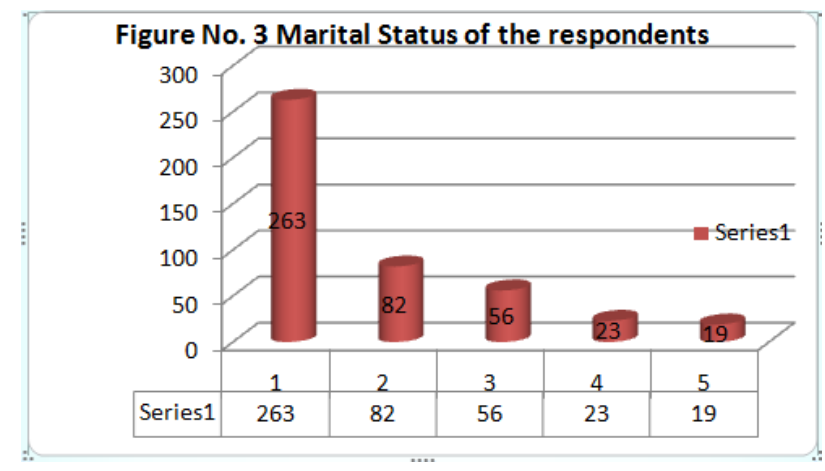

According to Table No. 04 out of 350 informants 231 are illiterate. It is painful to note that among the 217 females' informants as many as 158 are illiterate and 133 male informants as many as 73 are illiterate. Out of the total 21 informants who had studied up to Below Primary Level, 06 are male and only 15 are Female. Among the 48 who had Primary Education Level, 18 were male and only 30 were female, out of the total 14 informants who had studied up to Secondary Education 10 were male and only 04 were female. Among the 07 who had studied up to PUC level 05 male and only two were female out of the 19 informants who has studied up to 12 were male and 7 female under graduation level. Further among the 10 who studied up to Post Graduation Level 09 male and only one was a female. This high percent illiteracy among the female and fewer of them in other literate categories level the lesser important given to education for female by the society.

Table No. 04 Educational Status of the respondents

\begin{tabular}{|r|l|r|r|r|}
\hline \multirow{2}{*}{$\begin{array}{c}\text { Sl. } \\
\text { No. }\end{array}$} & \multicolumn{2}{|c|}{ Sex } & \multicolumn{1}{|}{ Female } & \multicolumn{1}{c|}{ Total } \\
\cline { 3 - 5 } & & Male & $158(72.8)$ & $231(66.0)$ \\
\hline 01 & Illiterate & $73(54.9)$ & $15(7.0)$ & $21(6.0)$ \\
\hline 02 & Below Primary & $06(4.5)$ & $30(13.8)$ & $48(13.7)$ \\
\hline 03 & Primary Education & $18(13.5)$ & $04(1.8)$ & $14(4.0)$ \\
\hline 04 & Secondary Education & $10(7.5)$ & $02(1.0)$ & $07(2.0)$ \\
\hline 05 & PUC Level & $05(3.8)$ & $07(3.2)$ & $19(5.4)$ \\
\hline 06 & Under Graduation & $12(9.0)$ & $01(0.4)$ & $10(2.0)$ \\
\hline 07 & Post Graduation & $09(6.8)$ & $\mathbf{2 1 7}(\mathbf{1 0 0})$ & \\
\hline
\end{tabular}

Note: Figures in parentheses are in percentage.

Figure No. 4 Educational Level of the respondents

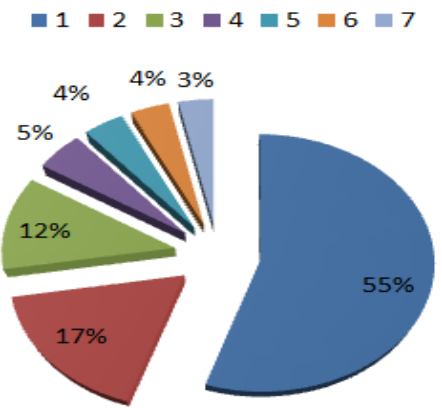

Table No. 05 Shows the Morbidity Status of the respondents. Conversation disabilities like Speech 268 (76.57 \%) elderly with difficulty and Hearing 199 (56.86\%) elderly with difficulty and another one important disabilities Visual 178 (50.86\%) elderly with difficulty.

Table No. 05 The General Disabilities of the respondents

\begin{tabular}{|c|c|c|c|c|c|c|c|c|c|c|}
\hline \multirow{3}{*}{$\begin{array}{l}\text { SI. } \\
\text { No }\end{array}$} & \multirow{3}{*}{$\begin{array}{c}\text { General } \\
\text { Disabilities }\end{array}$} & \multicolumn{3}{|c|}{ Conversation } & \multicolumn{3}{|c|}{ Hearing } & \multicolumn{3}{|c|}{ Visual } \\
\hline & & \multicolumn{3}{|c|}{ Sex } & \multicolumn{3}{|c|}{ Sex } & \multicolumn{3}{|c|}{ Sex } \\
\hline & & M & $\mathbf{F}$ & Total & $\mathbf{M}$ & $\mathbf{F}$ & Total & M & $\mathbf{F}$ & Total \\
\hline 01 & With difficulty & $\begin{array}{c}98 \\
(73.6)\end{array}$ & $\begin{array}{c}170 \\
(78.3)\end{array}$ & $\begin{array}{c}268 \\
(76.5)\end{array}$ & $\begin{array}{c}84 \\
(63.2)\end{array}$ & $\begin{array}{c}115 \\
(53.0)\end{array}$ & $\begin{array}{c}199 \\
(56.8)\end{array}$ & $\begin{array}{c}73 \\
(55.0)\end{array}$ & $\begin{array}{c}105 \\
(48.3)\end{array}$ & $\begin{array}{c}178 \\
(50.8)\end{array}$ \\
\hline 02 & Good & $\begin{array}{c}30 \\
(22.5)\end{array}$ & $\begin{array}{c}45 \\
(20.7)\end{array}$ & $\begin{array}{c}75 \\
(21.4)\end{array}$ & $\begin{array}{c}34 \\
(25.6)\end{array}$ & $\begin{array}{c}69 \\
(31.8)\end{array}$ & $\begin{array}{c}103 \\
(29.4)\end{array}$ & $\begin{array}{c}26 \\
(19.5)\end{array}$ & $\begin{array}{c}68 \\
(31.3)\end{array}$ & $\begin{array}{c}94 \\
(26.8)\end{array}$ \\
\hline 03. & Very Good & $\begin{array}{c}05 \\
(3.9)\end{array}$ & $\begin{array}{c}02 \\
(1.0)\end{array}$ & $\begin{array}{c}07 \\
(2.0)\end{array}$ & $\begin{array}{c}15 \\
(11.2)\end{array}$ & $\begin{array}{c}33 \\
(15.2)\end{array}$ & $\begin{array}{c}48 \\
(13.7)\end{array}$ & $\begin{array}{c}34 \\
(25.5)\end{array}$ & $\begin{array}{c}44 \\
(20.4)\end{array}$ & $\begin{array}{c}78 \\
(22.2)\end{array}$ \\
\hline & Total & $\begin{array}{c}133 \\
(100)\end{array}$ & $\begin{array}{c}217 \\
(100)\end{array}$ & $\begin{array}{c}350 \\
(100)\end{array}$ & $\begin{array}{c}133 \\
(100)\end{array}$ & $\begin{array}{c}217 \\
(100)\end{array}$ & $\begin{array}{c}350 \\
(100)\end{array}$ & $\begin{array}{c}133 \\
(100)\end{array}$ & $\begin{array}{c}217 \\
(100)\end{array}$ & $\begin{array}{c}350 \\
(100)\end{array}$ \\
\hline
\end{tabular}

Note: Figures in parentheses are in percentage. 
Table No. 06 Shows the Morbidity Status of the rural elderly over the last six months. 75.2 per cent of the elderly had some kind of health problems, and only 24.8 per cent reported that they did not have any problems. Among the respondents who reported some health problems, 73.6 per cent were males and 76.0 per cent were females. The health problems reported were joint pain (23.4\%), Hypertension (16.0 \%), Hearing Problem (6.5\%), Heart Diseases (5.4\%), Arthritis (5.1\%), Cataract (4.5\%), Chronic cough (4.2\%), Diabetes (4.0\%), Urinary Problems (2.0\%), Kidney Diseases (1.1\%), and Hernia only (0.2) per cent.

Table No. 06 The Morbidity Status in the last six months along with the Health Problems of the Respondents

\begin{tabular}{|c|c|c|c|c|}
\hline \multirow{2}{*}{$\begin{array}{l}\text { SI. } \\
\text { No. }\end{array}$} & \multirow{2}{*}{$\begin{array}{c}\begin{array}{c}\text { Prevalent Diseases of the } \\
\text { respondent }\end{array} \\
\end{array}$} & \multicolumn{2}{|c|}{ Sex } & \multirow[b]{2}{*}{ Total } \\
\hline & & Male & Female & \\
\hline \multirow[t]{13}{*}{01} & Problem & $98(73.6)$ & $165(76.0)$ & $263(75.2)$ \\
\hline & Joint Pain & $13(09.7)$ & $69(31.7)$ & $82(23.4)$ \\
\hline & Hypertension & $21(15.7)$ & $35(16.1)$ & $56(16.0)$ \\
\hline & Hearing Problems & $08(06.0)$ & $15(6.9)$ & $23(6.5)$ \\
\hline & Heart disease & $15(11.2)$ & $04(1.8)$ & $19(5.4)$ \\
\hline & Arthritis & $11(8.2)$ & $07(3.2)$ & $18(5.1)$ \\
\hline & Cataract & $09(6.7)$ & $07(3.2)$ & $16(4.5)$ \\
\hline & Chronic Cough & $03(2.2)$ & $12(5.5)$ & $15(4.2)$ \\
\hline & Diabetes & $05(3.7)$ & $09(4.1)$ & $14(4.0)$ \\
\hline & Cancer & $06(4.5)$ & $02(0.9)$ & $08(2.2)$ \\
\hline & Urinary Problem & $02(1.5)$ & $05(2.3)$ & $07(2.0)$ \\
\hline & Kidney disease & $04(3.0)$ & - & $04(1.1)$ \\
\hline & Hernia & $01(0.7)$ & - & $01(0.2)$ \\
\hline \multirow[t]{2}{*}{02} & No Problem & $35(26.4)$ & $52(24.0)$ & $87(24.8)$ \\
\hline & Total & $133(100)$ & $217(100)$ & $350(100)$ \\
\hline
\end{tabular}

Note: Figures in parentheses are in percentage.

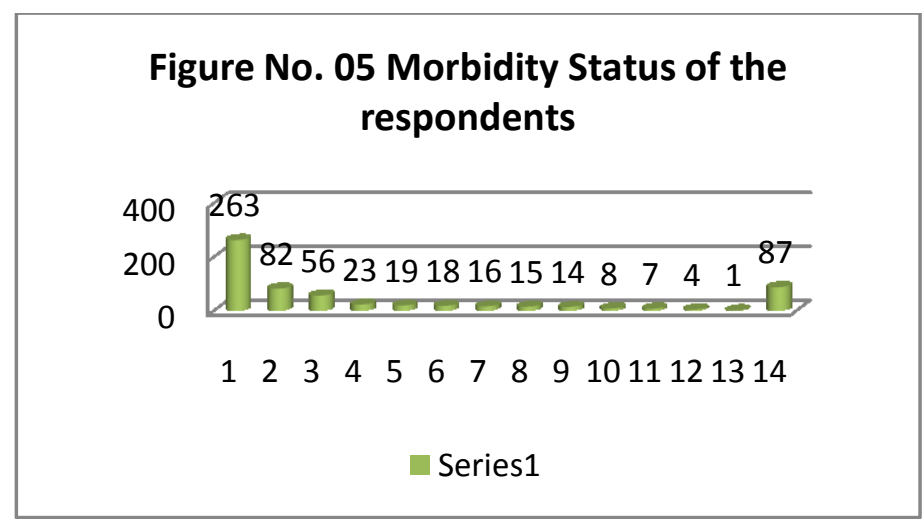

IV. Findings

The main findings of the study are as follows;

1. The majority of the respondents $(48.0 \%)$ belonged to the age groups of 60-69.

2. The majority of the respondents $(60.00 \%)$ of the belonged to Nuclear Family in area of study.

3. The majority of the respondents $(64.00 \%)$ of the belonged to Widowed Elderly Persons.

4. The majority of the respondents $(66.00 \%)$ of the belonged to Illiterate elderly.

5. The majority of the respondents $(75.0 \%)$ health problems of the aged persons.

6. A majority of the respondents were suffering from joint pain.

7. A majority of the respondents were goes to Government Hospital.

\section{Conclusion}

The study among the elderly in the rural area of Bagalkot District rural elderly persons are the growing population in our country. It is estimated that by the years 2050 . Elderly population will out reach the youth population and India will be in the first position all over the world. Health Problems is the most serious thing that has to be concerned by the society on the whole. It was observed that almost all the elderly suffer from one or the other disabilities like (23.4\%) joint problem, chronic diseases like hypertension, diabetes, heart diseases, cancer, paralysis, hernia, arthritis kidney diseases and cataract etc., Table No. 06 shows that all the respondents had health problems the very most common being hypertension, arthritis, diabetes, cancer, kidney diseases others included cataract, anemia, skin problems, hearing problems. It is seen that most of the respondents had 
more than one health problem. Arthritis was found to be more common among females while other health problems were almost similar among both the genders.

\section{References}

[1]. Chaturbhuja Sahu (1998) "Problems of Ageing among the Indian Tribes", New Delhi-02.

[2]. Hoyer W. J. and Roodin P. A. (2003) "Adult development and ageing”, New Yeark, McGaow Hill.

[3]. Vijay Kumar S (1998) "Health Services for the rural Elderly"; Social Change issues and perspectives". Journal of the council for social development.

[4]. World Health Organisation (1946) "Constitution of the World Health Organisation”, Publishing Health Report.

[5]. Camacho et al (1993) "Functional Ability in the oldest old", Journal of ageing and health.

[6]. Situational Analysis of the elderly in India: June 2011, Central Statistics office, Government of India.

[7]. Vinod Kumar (1996) “Ageing Indian Perspectives and Global Scenario", New Delhi.

[8]. John A. Ross (1982) "International Encyclopaedia of Population Center for population and family health.

[9]. K. Vijayakumar Et al (1992) "Life and Health of the elderly in a community in transition".

[10]. WHO Technical Report Series 779(1989) "Health of the Elderly", WHO, Genevo-1989. 